\title{
FAKTOR-FAKTOR YANG MEMPENGARUHI PERMINTAAN TAHU PUTIH DI KOTA MEDAN
}

\author{
M. Fahriza Ikhsan' ${ }^{1)}$ Retna Astuti K ${ }^{2{ }^{*}}$ Faoeza Hafiz Saragih ${ }^{3)}$ \\ Program Studi Agribisnis Fakultas Pertanian Universitas Medan Area \\ E-mail : retnotutik60@gmail.com
}

\begin{abstract}
ABSTRAK
Tahu merupakan salah satu bahan pangan yang memegang peranan untuk keseimbangan gizi dan menjadi salah satu lauk-pauk favorit masyarakat. Tujuan penelitian ini adalah untuk mengetahui faktor apa saja yang mempengaruhi permintaan konsumen terhadap tahu putih di Kota Medan. Metode pengambilan sampel dilakukan dengan metode purposive sampling. Responden dalam penelitian ini adalah konsumen yang mengonsumsi tahu putih dalam rumah tangga. Informasi diperoleh dari penjual tahu putih di Pasar Petisah, Pasar Sei Sikambing dan Pasar Helvetia dan sampel yang diambil adalah 45 responden, masing-masing 15 responden di setiap pasar. Data yang dikumpulkan adalah data primer dan data sekunder. Metode analisis yang digunakan adalah uji regresi linier berganda dengan alat bantu SPSS 20 . Hasil penelitian ini menyimpulkan bahwa variabel harga tahu putih, harga tempe, harga ikan, pendapatan dan jumlah tanggungan secara serempak berpengaruh signifikan terhadap permintaan tahu putih di Kota Medan. Secara parsial variabel harga tahu putih dan harga ikan berpengaruh signifikan terhadap permintaan tahu putih di Kota Medan, sedangkan variabel harga tempe, pendapatan dan jumlah tanggungan tidak berpengaruh signifikan terhadap permintaan tahu putih di Kota Medan.
\end{abstract}

Kata Kunci : Harga, Jumlah Tanggungan, Pendapatan, Tahu Putih

\begin{abstract}
Tofu is one of the foodstuffs that plays a role for nutritional balance and is one of the people's favorite side dishes. The purpose of this study is to find out what factors influence consumer demand for white tofu in the city of Medan. The sampling method is done by purposive sampling method. Respondents in this study were consumers who consumed white tofu in the household. Information obtained from white tofu sellers in Petisah Market, Sei Sikambing Market and Helvetia Market and samples taken were 45 respondents, each 15 respondents in each market. Data collected are primary data and secondary data. The analytical method used is multiple linear regression test with SPSS 20. The results of this study concluded that the variable price of white tofu, tempe prices, fish prices, income and the number of dependents simultaneously had a significant effect on the demand for white tofu in Medan. Partially the variable price of white tofu and fish prices has a significant effect on the demand for white tofu in Medan, while the variable price of tempe, income and the number of dependents does not significantly influence the demand for white tofu in Medan.
\end{abstract}

Keywords: Price, Amount of Dependent, Income, White Tofu 


\section{PENDAHULUAN}

Pangan merupakan kebutuhan dasar manusia yang paling utama dan pemenuhannya merupakan bagian dari hak asasi manusia yang dijamin di dalam Undang-Undang Dasar Negara Indonesia tahun 1945. Menurut Kemenkes (2005) pemenuhan kebutuhan pangan juga terkait dengan upaya peningkatan kualitas kesehatan masyarakat sehingga diperoleh kualitas sumber daya Indonesia yang mempunyai daya saing tangguh dan unggul sebagai bangsa. Sumber daya manusia berkualitas digambarkan sebagai manusia sehat yang cerdas, produktif dan mandiri.

Salah satu upaya pemerintah adalah melalui diversifikasi pangan dan gizi. Program diversifikasi pangan sebetulnya sudah dirintis sejak awal dasawarsa 60-an, dimana pemerintah telah menyadari pentingnya dilakukan diversifikasi tersebut. Tujuan dilakukan program diversifikasi pangan untuk memvariasikan konsumsi masyarakat Indonesia agar tidak terfokus pada nasi. Salah satu komoditi yang sering dimanfaatkan masyarakat dalam pemenuhan kebutuhan pangan yaitu kacang-kacangan seperti kacang kedelai, kacang tanah, biji kecipir, koro, dan lain-lain. Kacang kedelai merupakan salah satu bahan pangan nabati yang sangat penting sebagai sumber protein. Salah satu olahan kacang kedelai adalah tahu. Tahu merupakan salah satu bahan pangan yang memegang peranan untuk keseimbangan gizi dan menjadi salah satu lauk-pauk favorit masyarakat. Tahu dibuat dari ekstrak protein kedelai yang telah digumpalkan dengan asam, ion kalsium, dan bahan penggumpal lainnya. Tahu begitu popular sebagai makanan murah yang kaya gizi. Kandungan rendah lemak dan tinggi asam lemak omega 3 yang terdapat dalam bahan baku utamanya kedelai sehingga dapat dimanfaatkan untuk menjaga kesehatan tubuh (Cahyadi, 2009).

Berdasarkan data Badan Pusat Statistik dan Pusdatin menunjukkan konsumsi tahu dalam rumah tangga di Indonesia pada tahun 2012 sampai 2016 cenderung mengalami peningkatan dengan rata-rata $7,29 \mathrm{~kg} / \mathrm{kapita} / \mathrm{tahun}$. Hal ini disebabkan oleh harga tahu tergolong jauh lebih murah dan mengingat kebutuhan masyarakat pentingnya mengkonsumsi protein. Konsumsi tahu di Indonesia pada tahun 2017-2019 diprediksikan akan meningkat. Kebutuhan terhadap konsumsi pangan akan terus meningkat dari tahun ke tahun seiring dengan pertumbuhan penduduk yang tak kenal lapisan masyarakat, permintaan tahu tergolong tinggi, terutama pasar dalam negeri.

Berdasarkan data Badan Pusat Statistik menunjukkan konsumsi tahu dalam rumah tangga di Sumatera Utara pada tahun 2013 sampai 2017 cenderung mengalami fluktuatif dengan rata-rata $0,37 \mathrm{~kg} / \mathrm{kapita} / \mathrm{bulan}$. Hal tersebut disebakan oleh harga barang pengganti yang setiap saat bisa terjadi perubahan harga yang akan mempengaruhi tingkat konsumsi tahu. Tetapi jumlah konsumsi tahu di Sumatera Utara ini lebih dari empat kali lipat jika 
dibandingkan dengan tingkat konsumsi daging sapi yang merupakan sumber protein hewani. Alasan konsumen untuk mengonsumsi tahu itu berbeda-beda dari tiap kalangan, untuk kelas ekonomi atas alasan mengonsumsi tahu karena kandungan gizi yang terdapat dalam tahu, sedangkan untuk kelas ekonomi menengah dan bawah alasan mengonsumsi tahu karena harganya yang murah serta terjangkau.

Umumnya masyarakat Kota Medan lebih cenderung setiap harinya mengkonsumsi lauk pauk hewani yang berasal dari ikan dan menjadikan ikan sebagai lauk utama didalam rumah tangga. Hal ini disebabkan karena kandungan protein ikan jauh lebih tinggi. Namun bagi sebagian masyarakat Kota Medan yang berpendapatan rendah tidak mampu mengkonsumsi ikan secara rutin setiap harinya dikarenakan harga relatif mahal. Sehingga tahu putih menjadi salah satu alternatif lauk pauk bagi masyarakat Kota Medan dengan harga yang murah serta terjangkau dan memenuhi syarat gizi yang terkandung didalamnya protein nabati, lemak, kalsium dan energi.

Berdasarkan latar belakang, maka diperlukan suatu kajian atau penelitian yang membahas mengenai faktor-faktor yang mempengaruhi permintaan tahu putih Kota Medan, baik bagi konsumen dari golongan ekonomi bawah, menengah, dan atas. Sehingga dapat diketahui faktor-faktor apa saja yang berpengaruh terhadap permintaan tahu putih di Kota Medan.

\section{METODE PENELITIAN}

Lokasi penelitian ditentukan secara sengaja (purposive) dibeberapa pasar tradisional yang ada di Kota Medan. Pasar tradisional yang dipilih sebagai lokasi penelitian adalah Pasar Petisah di Kecamatan Medan Petisah, Pasar Sei Sikambing di Kecamatan Medan Helvetia, dan Pasar Inpres Helvetia di Kecamatan Medan Helvetia. Waktu penelitian dilakukan pada Bulan Mei sampai Agustus 2018. Dalam penelitian ini yang menjadi populasi adalah konsumen tahu putih di lokasi penelitian. Keadaan populasi tersebut cenderung homogen. Metode penentuan sampel dilakukan dengan metode (Purposive Sampling) yaitu sampel secara sengaja dilakukan dengan memilih sampel yang sesuai dengan kriteria tertentu dan mengabaikan yang tidak sesuai dengan kriteria tersebut. Kriteria yang dijadikan sampel dalam penelitian ini yaitu konsumen yang mengkonsumsi tahu putih di dalam rumah tangga dan jumlah tahu putih yang dikonsumsi 1 - 10 potong. Besar sampel konsumen tahu putih dalam penelitian ini ditetapkan sebanyak 45 responden, masing-masing 15 responden di setiap pasar lokasi penelitian. Data yang dikumpulkan berupa data primer dan data sekunder. Metode analisis data dalam penelitian ini menggunakan metode Analisis Regresi Berganda dengan alat bantu SPSS. Data yang dibutuhkan adalah harga tahu putih, harga tempe, harga ikan, pendapatan konsumen dan jumlah tanggungan dengan menggunakan rumus : 


$$
\mathrm{Y}=\mathrm{b}_{0}+\mathrm{b}_{1} \mathrm{X}_{1}+\mathrm{b}_{2} \mathrm{X}_{2}+\mathrm{b}_{3} \mathrm{X}_{3}+\mathrm{b}_{4} \mathrm{X}_{4}+\mathrm{b}_{5} \mathrm{X}_{5}+\mathrm{e}
$$

Keterangan :

$\mathrm{Y}=$ jumlah permintaan tahu putih (Potong/100gr/Bulan)

$\mathrm{b}_{0}=$ Konstanta

$\mathrm{X}_{1}=$ Harga Tahu Putih (Rp/Potong/100gr)

$\mathrm{X}_{2}=$ Harga Tempe $(\mathrm{Rp} /$ Bungkus/250gr)

$\mathrm{X}_{3}=$ Harga Ikan $(\mathrm{Rp} / \mathrm{Kg})$

$\mathrm{X}_{4}=$ Pendapatan Konsumen (Rp/Bulan)

$\mathrm{X}_{5}=$ Jumlah Tanggungan (Orang)

$\mathrm{e}=$ Standar Eror

\section{HASIL DAN PEMBAHASAN}

\section{Analisis Regresi Linier Berganda}

Berdasarkan hasil perhitungan dengan menggunakan alat bantu SPSS 20, hasil yang diperoleh untuk perhitungan regresi linier berganda dari FAKTOR-FAKTOR YANG MEMPENGARUHI PERMINTAAN TAHU PUTIH DI KOTA MEDAN dapat dilihat pada

Tabel 1 .

Tabel 1. Hasil Perhitungan dari Faktor-Faktor Yang Mempengaruhi Permintaan Tahu Putih di Kota Medan

\begin{tabular}{llll}
\hline Variabel & B & T-Hitung & Signifikan \\
\hline Konstanta & 154,659 & 5,205 & 0,000 \\
X1= Harga Tahu Putih & $-0,028$ & $-2,557$ & 0,015 \\
X2= Harga Tempe & 0,020 & 1,698 & 0,098 \\
X3= Harga Ikan & $-0,004$ & $-4,596$ & 0,000 \\
X4= Pendapatan & $-1,719 \mathrm{E}-006$ & $-0,517$ & 0,608 \\
X5= Jumlah Tanggungan & 1,976 & 0,598 & 0,554 \\
\hline
\end{tabular}

R-Square $=0,423$

F-hitung $=5,722$

F-tabel $=2,456$

T-tabel $=2,023$

Sumber: Data Primer diolah (2018)

Berdasarkan Tabel hasil analisis regresi linier berganda maka adapun persamaan sebagai berikut :

$\mathrm{Y}=154,659-0,028 \mathrm{X} 1+0,020 \mathrm{X} 2-0,004 \mathrm{X} 3-0,000001719 \mathrm{X} 4+1,976 \mathrm{X} 5$

Keterangan :

$Y=$ jumlah permintaan tahu putih (Potong/100gr/Bulan)

$\mathrm{b}=$ Koefisien Regresi (nilai $\mathrm{Y}$ apabila $\mathrm{X}=0$ )

$a=$ Konstanta

$\mathrm{X} 1$ = Harga Tahu Putih (Rp/Potong/100gr)

$\mathrm{X} 2$ = Harga Tempe (Rp/Bungkus/250gr)

X3 = Harga Ikan $(\mathrm{Rp} / \mathrm{Kg})$ 


$$
\begin{aligned}
& \text { X4 = Pendapatan Konsumen (Rp/Bulan) } \\
& \text { X5 = Jumlah Tanggungan (Orang) }
\end{aligned}
$$

Berdasarkan persamaan tersebut dapat diketahui bahwa :

1. Konstanta $(a)=154,659$ menunjukkan nilai konstanta, jika nilai harga tahu putih (X1), harga tempe (X2), harga ikan (X3), pendapatan (X4) dan jumlah tanggungan $(\mathrm{X} 5)=0$ maka permintaan tahu putih (Y) akan sebesar 154,659 potong.

2. Koefisien regresi variabel harga tahu putih (X1) sebesar -0,028 artinya jika harga tahu putih mengalami kenaikan harga sebesar Rp 1.000 maka permintaan tahu putih akan mengalami penurunan sebesar 28 potong.

3. Koefisien regresi variabel harga tempe (X2) sebesar 0,020 artinya jika harga tempe mengalami kenaikan harga sebesar Rp 1.000 maka permintaan tahu putih akan mengalami peningkatan sebesar 20 potong.

4. Koefisien regresi variabel harga ikan (X3) sebesar -0,004 artinya jika harga ikan mengalami kenaikan harga sebesar Rp 1.000 maka permintaan tahu putih akan mengalami penurunan sebesar 0,4 potong.

5. Koefisien regresi variabel pendapatan (X4) sebesar -0,000001719 artinya jika pendapatan mengalami kenaikan sebesar Rp 1.000 maka permintaan tahu putih akan mengalami penurunan sebesar 0,0001719 potong.

6. Koefisien regresi variabel jumlah tanggungan (X5) sebesar 1,976 artinya bahwa penambahan 1 orang tanggungan keluarga, maka permintaan tahu putih akan mengalami peningkatan sebesar 1,976 potong.

\section{a. Koefisien Determinasi ( )}

Setelah dilakukan analisis terhadap model regresi linier berganda tersebut, maka diperoleh hasil sebesar 0,423 yang artinya 42,3\% variasi variabel jumlah Permintaan Tahu Putih telah dapat dijelaskan oleh variabel harga tahu putih, harga tempe, harga ikan, pendapatan, dan jumlah tanggungan. Sisanya sebesar 57,7 \% dijelaskan oleh faktor-faktor lain yang tidak diteliti dalam penelitian ini. Adapun faktor-faktor lain yang diduga mempengaruhi permintaan tahu putih di Kota Medan adalah harga telur dan selera.

\section{b. Uji F}

Berdasarkan Tabel 10 dapat dilihat bahwa secara serempak variabel harga tahu putih, harga tempe, harga ikan, pendapatan dan jumlah tanggungan ternyata berpengaruh secara signifikan terhadap permintaan tahu putih, secara statistik pada $=5 \%$. Hal ini dapat dilihat dari uji F, dimana F-hitung $(5,722)>$ F-tabel $(2,456)$, maka H0 ditolak. Sehingga dapat disimpulkan bahwa secara serempak variabel harga tahu putih, harga tempe, harga ikan, pendapatan dan jumlah tanggungan berpengaruh nyata terhadap Permintaan Tahu Putih. 


\section{c. Uji t}

Uji t digunakan untuk menguji nyata atau tidaknya pengaruh variabel bebas (Independent Variabel) secara individu terhadap permintaan tahu putih sebagai variabel terikat (Dependent Variabel).

\section{Harga Tahu Putih (X1)}

Berdasarkan Tabel 10 hasil uji signifikansi secara parsial dapat diambil kesimpulan perbandingan $t$ hitung dengan $\mathrm{t}$ tabel yaitu nilai $\mathrm{t}$ hitung $>\mathrm{t}$ tabel $(2,557>2,023)$ maka $\mathrm{H} 0$ ditolak ; H1 diterima dan tingkat signifikansi $(0,015<0,05)$ artinya bahwa harga tahu putih secara parsial berpengaruh signifikan terhadap permintaan tahu putih. Nilai t hitung negatif, artinya jika harga tahu putih mengalami peningkatan maka permintaan tahu putih mengalami penurunan.

\section{Harga Tempe (X2)}

Berdasarkan Tabel 10 hasil uji signifikansi secara parsial dapat diambil kesimpulan perbandingan $\mathrm{t}$ hitung dengan $\mathrm{t}$ tabel yaitu nilai $\mathrm{t}$ hitung < $\mathrm{t}$ tabel $(1,698<2,023)$ maka $\mathrm{H} 0$ diterima ; H1 ditolak dan tingkat signifikansi $(0,98>0,05)$ artinya bahwa harga tempe secara parsial tidak berpengaruh signifikan terhadap permintaan tahu putih.

\section{Harga Ikan (X3)}

Berdasarkan Tabel 10 hasil uji signifikansi secara parsial dapat diambil kesimpulan perbandingan $t$ hitung dengan $t$ tabel yaitu nilai $t$ hitung $>\mathrm{t}$ tabel $(4,596>2,023)$ maka H0 ditolak ; H1 diterimadan tingkat signifikansi $(0,000<0,05)$ artinya bahwa harga ikan secara parsial berpengaruh signifikan terhadap permintaan tahu putih. Nilai t hitung negatif, artinya jika harga ikan mengalami peningkatan maka permintaan tahu putih mengalami penurunan.

\section{Pendapatan (X4)}

Berdasarkan Tabel 10 hasil uji signifikansi secara parsial dapat diambil kesimpulan perbandingan $t$ hitung dengan $t$ tabel yaitu nilai $t$ hitung $<\mathrm{t}$ tabel $(0,517<2,023)$ maka $\mathrm{H} 0$ diterima ; H1 ditolak dan tingkat signifikansi $(0,608>0,05)$ artinya bahwa pendapatan secara parsial tidak berpengaruh signifikan terhadap permintaan tahu putih. Nilai t hitung negatif, artinya jika pendapatan mengalami peningkatan maka permintaan tahu putih mengalami penurunan.

\section{Jumlah Tanggungan (X5)}

Berdasarkan Tabel 10 hasil uji signifikansi secara parsial dapat diambil kesimpulan perbandingan $\mathrm{t}$ hitung dengan $\mathrm{t}$ tabel yaitu nilai $\mathrm{t}$ hitung < $\mathrm{t}$ tabel $(0,554<2,023)$ maka $\mathrm{H} 0$ diterima ; H1 ditolak dan tingkat signifikansi $(0,554>0,05)$ artinya bahwa jumlah tanggungan secara parsial tidak berpengaruh signifikan terhadap permintaan tahu putih. 


\section{PEMBAHASAN}

\section{Harga Tahu putih (X1)}

Harga tahu putih pada setiap pasar berbeda, dari data yang didapat bahwa harga tahu putih terendah adalah sebesar Rp 1.000/potong dan harga tahu putih yang tertinggi adalah sebesar Rp 2.000/potong dapat dilihat pada. Berdasarkan hasil uji statistik pada tingkat kepercayaan $95 \%$, tingkat signifikansi $(0,015<0,05)$ dapat disimpulkan bahwa harga ikan secara parsial berpengaruh signifikan terhadap permintaan tahu putih.

Semakin mahal harga tahu putih maka permintaan terhadap tahu putih semakin menurun. Hal ini sesuai dengan teori dimana menurut Pracoyo (2006) yang menyatakan bahwa hubungan antara harga barang dan jumlah barang yang diminta adalah negatif. Bila harga naik maka permintaan turun dan sebaliknya bila harga turun permintaan akan naik dengan asumsi cateris paribus. Tahu memang dikenal sebagai makanan yang merakyat, hal ini karena harga tahu yang sangat terjangkau. Selain murah tahu kaya akan kandungan gizi baik bagi tubuh. Dari hasil data penelitian rata-rata konsumen menjadikan tahu putih sebagai lauk tambahan atau pelengkap di dalam rumah tangga. Permintaan tahu putih di Kota Medan sangat tinggi dari data yang didapatkan bahwa permintaan tahu putih terendah yaitu sebesar 12 potong/bulan dan permintaan tahu putih tertinggi yaitu sebesar 140 potong/bulan dengan rata-rata permintaan tahu putih yaitu sebesar 71 potong/bulan.

\section{Harga Tempe $\left(\mathrm{X}_{2}\right)$}

Harga tempe pada setiap pasar berbeda, dari data yang didapat bahwa harga tempe terendah adalah sebesar Rp 2.000/bungkus dan harga tempe yang tertinggi adalah sebesar Rp 3.500/bungkus. Berdasarkan hasil uji statistik pada tingkat kepercayaan 95\%, tingkat signifikansi $(0,098>0,05)$ dapat disimpulkan bahwa harga tempe secara parsial tidak berpengaruh signifikan terhadap permintaan tahu putih.

Menurut teori yang dikemukakan oleh Daniel (2004) terjadinya perubahan harga pada suatu barang akan berpengaruh terhadap permintaan barang lain. Keadaan ini terjadi jika kedua barang tersebut mempunyai hubungan yang saling melengkapi (complementer).

Hal ini disebabkan karena perbandingan harga tempe tidak jauh berbeda dengan harga tahu putih. Dari hasil data yang didapat responden membeli tempe dan tahu putih juga secara bersamaan untuk lauk pelengkap yang akan dijadikan sayur didalam konsumsi rumah tangga sehingga dapat disimpulkan bahwa tempe merupakan pelengkap tahu putih untuk dijadikan sayur dalam konsumsi rumah tangga di Kota Medan. Ada beberapa jenis sayur yang dapat di campur dengan tempe dan tahu, contohnya adalah sayur kacang panjang yang di tumis/osengoseng dapat dicampur tahu dan tempe. Tempe dan tahu adalah makanan dengan harga yang 
relatif murah dengan segudang manfaat bagi tubuh manusia, manfaat yang di kandung tahu dan tempe berasal dari biji kedelai selaku bahan utama pembuatan tahu dan tempe.

\section{Harga Ikan (X3)}

Berdasarkan hasil uji statistik pada tingkat kepercayaan 95\%, tingkat signifikansi $(0,000<0,05)$ dapat disimpulkan bahwa harga ikan secara parsial berpengaruh signifikan terhadap permintaan tahu putih.

Menurut teori yang dikemukakan oleh Rahardja dan Manurung (2008) Harga barang pengganti dapat mempengaruhi permintaan barang yang dapat digantikannya. Sekiranya harga barang pengganti bertambah murah, maka barang yang digantikannya akan mengalami pengurangan dalam permintaan sedangkan menurut teori yang dikemukakan oleh Sukirno (2009) apabila sesuatu barang selalu digunakan bersama dengan barang lainnya, maka barang tersebut dinamakan barang pelengkap kepada barang lain tersebut. Kenaikan dan penurunan permintaan terhadap barang pelengkap selalu sejalan dengan perubahan permintaan barang yang digenapinya.

Berdasarkan data hasil penelitian bahwa responden menjadikan ikan sebagai lauk utama dalam rumah tangga sedangkan tahu putih dijadikan sebagai lauk tambahan atau pelengkap dalam konsumsi rumah tangga. Dapat diasumsikan bahwa ketika suatu rumah tangga yang mengkonsumsi ikan dan tahu putih pada saat harga ikan naik dan harga tahu putih tetap (ceteris paribus) maka jumlah permintaan tahu putih akan berkurang. Hal ini disebabkan karena suatu rumah tangga tersebut telah membeli ikan dengan harga yang tinggi sehingga tahu putih yang akan dibeli hanya untuk melengkapi ikan saja yang telah dibeli tersebut. Hal ini juga disebabkan karena masyarakat (rumah tangga) tersebut beralih ke pangan jenis lainnya dengan tidak membeli ikan maupun tahu putih sehingga permintaan tahu putih berkurang. Dapat diketahui berdasarkan data hasil penelitian tingkat konsumsi pilihan konsumen yaitu Ikan - Tahu Putih - Tempe menduduki tingkat kesukaan yang pertama dengan persentase 67\%, Tahu Putih - Ikan - Tempe menduduki tingkat kesukaan yang kedua dengan persentase $31 \%$, sedangkan Tempe - Tahu Putih - Ikan menduduki tingkat kesukaan yang ketiga dengan persentase $2 \%$.

\section{Pendapatan $\left(\mathrm{X}_{4}\right)$}

Daya beli masyarakat dapat dilihat melalui pendapatannya, jika pendapatan yang diperolehnya cukup tinggi, maka pada umumnya daya beli masyarakat cukup tinggi. Pendapatan responden per bulan konsumen tahu putih dalam penelitian ini sangat bervariasi, mulai dari Rp 1.000.000 sampai Rp 7.500.000. Berdasarkan hasil uji statistik pada tingkat kepercayaan $95 \%$, tingkat signifikansi $(0,608>0,05)$ dapat disimpulkan bahwa pendapatan secara parsial tidak berpengaruh signifikan terhadap permintaan tahu putih. 
Menurut teori yang dikemukakan oleh Pracoyo (2006), hubungan antara pendapatan dengan jumlah barang yang diminta adalah positif. Bila pendapatan seseorang/masyarakat meningkat maka akan meningkatkan permintaan terhadap suatu barang. Namun hal ini terjadi bila barang yang dimaksud adalah barang normal. Apabila jenis barang yang dimaksud adalah barang yang berkualitas rendah maka dengan adanya kenaikan pendapatan, konsumen justru akan mengurangi permintaan terhadap barang tersebut.

Berdasarkan data hasil penelitian pendapatan dari responden tersebut tidak dapat menentukan seberapa besar pengaruhnya terhadap permintaan tahu putih. Berdasarkan dari hasil data penelitian bahwa jumlah pendapatan sampel yang paling tinggi adalah $<2.900 .000$ sebanyak 22 orang dan yang paling rendah adalah $>4.000 .000$ sebanyak 11 orang. Hal ini disebabkan karena tahu putih merupakan barang inferior yang banyak diminta oleh orangorang yang berpendapatan yang menengah ke bawah. Pada pendapatan yang sangat rendah masyarakat yang mengkonsumsi tahu putih sebagai lauk utama didalam rumah tangga. Kalau pendapatan meningkat maka konsumen mempunyai kemampuan membeli daging sapi atau ikan untuk mengurangi konsumsinya terhadap tahu putih.

\section{Jumlah Tanggungan (X5)}

Berdasarkan dari hasil data penelitian bahwa jumlah tanggungan sampel yang paling tinggi adalah 1 - 3 sebanyak 32 responden dan yang paling rendah adalah 4 - 6 sebanyak 13 responden. Berdasarkan hasil uji statistik pada tingkat kepercayaan 95\%, tingkat signifikansi $(0,554>0,05)$ dapat disimpulkan bahwa jumlah tanggungan secara parsial tidak berpengaruh signifikan terhadap permintaan tahu putih.

Menurut teori yang dikemukakan oleh Daniel (2004) Pertambahan anggota keluarga akan mempengaruhi kuantitas kebutuhan suatu komoditas sehingga permintaan terhadap komoditas tersebut akan meningkat pula. Sehingga dapat dikatakan bahwa permintaan suatu barang berhubungan positif dengan jumlah anggota keluarga.Semakin banyak jumlah anggota keluarga, maka semakin banyak pula permintaan barang untuk dikonsumsi.

Berdasarkan hasil data jumlah tanggungan dari responden tersebut tidak dapat menentukan seberapa besar pengaruhnya terhadap permintaan tahu putih. Hal ini disebabkan karena responden dengan jumlah tanggungan $1-3$ jiwa merupakan responden rumah tangga yang paling banyak yang berjumlah 32 responden dengan rata-rata konsumsi tahu putih 63 potong/bulan. Sedangkan jumlah tanggungan yang paling banyak $4-6$ jiwa hanya berjumlah 13 responden dengan rata-rata konsumsi tahu putih 57 potong/bulan. Hal ini juga disebabkan karena jarak dari jumlah tanggungan yang kecil/rapat serta jumlah konsumsi tahu putih hanya berbeda sedikit yaitu 6 potong/bulan.Sehingga jumlah tanggungan dari kedua kelompok 
responden tersebut tidak dapat menentukan seberapa besar pengaruhnya terhada permintaan tahu putih di Kota Medan.

\section{SIMPULAN}

Berdasarkan hasil penelitian dan pembahasan pada bab sebelumnya, maka kesimpulan yang dapat dikemukakan dalam penelitian ini adalah hasil uji t didapat bahwa secara parsial variabel harga tahu putih dan harga ikan berpengaruh signifikan terhadap permintaan tahu putih di Kota Medan sedangkan variabel harga tempe, pendapatan dan jumlah tanggungan tidak berpengaruh signifikan terhadap permintaan tahu putih di Kota Medan.

\section{DAFTAR PUSTAKA}

Barus, Apriyani. 2013. Analisis Permintaan Dan Penawaran Kedelai Di Sumatera Utara. Skripsi. Universitas Sumatera Utara.

Cahyadi, W. 2007. Kedelai, Khasiat dan Teknologi. Jakarta (ID): PT Bumi Aksara.

Daniel, M. 2004. Pengantar Ekonomi Pertanian. Bumi Aksara. Jakarta.

Fitriani. 2017. Faktor-Faktor Yang Mempengaruhi Permintaan Tahu Di Gampong Pante Gajah Kecamatan Peusangan Kabupaten Bireuen (Studi Kasus Konsumen Tahu Pada Agroindustri Bapak Ari Gunawan). Jurnal S. Pertanian 1 (1): 88-96.

Hanafi, F, I. 2014. Analisis Faktor-Faktor yang Mempengaruhi Permintaan Tempedi Kelurahan Jurangmangu Timur, Pondok Aren, Tangerang Selatan. Jurnal Agribisnis 8 (1): 45-58.

Pracoyo, A. 2006. Aspek Dasar Ekonomi Mikro. PT. Gramedia Widiasarana Indonesia. Jakarta.

Rahmanta, 2015. Faktor-Faktor yang Mempengaruhi Permintaan Kedelai di Provinsi Sumatera Utara. QE Journal 4 (1): 1-12.

Styawan, F. 2016. Permintaan Kedelai Pada Industri Rumah Tangga Tahu Di Kabupaten Sleman. Jurnal Agro Ekonomi 27 (2): 215-232.

Sukirno, S. 2005. Mikro Ekonomi Teori Pengantar Edisi Ketiga. PT. Raja Grafindo Persada. Jakarta. 